\title{
Pengaruh Likuiditas, Profitabilitas dan Manajemen Laba terhadap Pengungkapan Sukarela (Voluntary Disclosure)
}

(Studi Empiris Pada Perusahaan High and Low Technology yang

Terdaftar di Bursa Efek Indonesia Tahun 2014-2018)

\section{Akuntansi}

\author{
Syarifa Nur Mutiara Wanti ${ }^{1 *}$, Dewi Indriasih' ${ }^{2}$, Aminul Fajri ${ }^{3}$ \\ Fakultas Ekonomi dan Bisnis, Universitas Pancasakti Tegal \\ Email: sysyarifa0497@gmail.com
}

\begin{abstract}
ABSTRAK
Tujuan penelitian adalah untuk mengetahui pengaruh likuiditas, profitabilitas dan manajemen laba terhadap pengungkapan sukarela. Metode pengumpulan data yang digunakan dalam penelitian adalah metode dokumentasi. Sedangkan metode analisis data yang digunakan adalah analisis deskriptif, uji asumsi klasik, dan pengujian hipotesis. Populasi dalam penelitian ini adalah perusahaan high and low technology yang terdaftar di BEI pada periode 2014-2018. Sampel pada penelitian ini 19 perusahaan yang telah diseleksi dengan metode purposive sampling. Berdasarkan hasil uji signifikansi linier berganda likuiditas diperoleh sig. sebesar 0,006>0,05, sehingga dapat disimpulkan terdapat pengaruh yang signifikan terhadap pengungkapan sukarela. Hasil pengujian signifikansi analisis regresi linier berganda profitabilitas sig. sebesar $0,048<0,05$, sehingga dapat disimpulkan terdapat pengaruh yang signifikan terhadap pengungkapan sukarela. Hasil pengujian signifikansi analisis regresi linier berganda manajemen laba diperoleh sig. sebesar 0,615>0,05, sehingga dapat disimpulkan tidak terdapat pengaruh yang signifikan terhadap pengungkapan sukarela
\end{abstract}

Kata kunci: likuiditas, profitabilitas, manajemen laba, pengungkapan sukarela.

\section{PENDAHULUAN}

Era globalisasi saat ini atau yang dinamakan Era 4.0 yang dimana semua kegiatan berbasis menggunakan teknologi canggih yang dapat memudahkan pekerjaan manusia menjadi ringan, cepat dan efisien. Hal ini juga terjadi pada perekonomian Indonesia, dimana semua pelaku bisnis menggunakan strategi bisnis yang dapat menguntungkan perusahaan maupun masyarakat. Informasi keuangan suatu perusahaan merupakan hal yang penting dalam persaingan di dunia bisnis saat ini. Hal ini dikarenakan informasi yang tersaji dalam laporan tahunan menjadi suatu pertimbangan bagi para pengambil keputusan baik pihak internal maupun eksternal perusahaan. Agar informasi yang disajikan dalam laporan keuangan dapat dipahami, maka penyajian laporan tersebut harus disertai dengan pengungkapan yang cukup. (Neliana, 2018)

Saat ini pengungkapan wajib saja dianggap tidak memadai untuk menilai kinerja sebuah perusahaan, sehingga perusahaan dituntut untuk melakukan pengungkapan secara lebih dengan alasan transparansi dalam menjelaskan kondisi perusahaan yang sebenarnya kepada publik atau pihak lain yang berkepentingan. Menurut Healy (1993) pengungkapan 
sukarela merupakan salah satu cara yang dilakukan manajer untuk memperbaiki kredibilitas pelaporan keuangannya (Wardani, 2012).

Fenomena perkembangan isu Disclosure laporan keuangan perusahaan yang di bahas salah satu media berita online baru-baru ini yaitu pada PT. Tiga Pilar Sejahtera Food Tbk (AISA) atau TPS Food yang menjadi perbincangan kembali karena pasca keluarnya laporan hasil investigasi dari Auditor Eksternal Ernst \& Young Indonesia (EY) setelah pergantian manajemen yang baru. Dalam laporan seebal 109 halaman terdaapat adanya dugaan aliran dana sebesar Rp. 1,78 Triliun dengan berbagai skema dari TPS Food Grup kepada pihakpihak yang diduga terafiliasi dengan manajemen lama. Hasil investigasi penyelidikan terhadap laporan keuangan tahun 2017, TPS Food mendapati dugaan adanya penggelembungan keuangan (financial overstatement) senilai 4 trilliun yang dilakukan manajemen lama pada beberapa pos akuntansi (akun piutang usaha, persediaan dan asset milik TPS Food Grup).

\section{LITERATUR DAN PENGEMBANGAN HIPOTESIS \\ Teori Keagenan}

Teori Agensi merupakan teori yang berhubungan agent dengan principal, teori ini ditemukan oleh Jensen dan Mackling (1976) merupakan orang pertama yang memasukkan unsur manusia dalam model yang terpadu tentang perilaku perusahaan. Dalam model tersebut, perusahaan digambarkan sebagai kumpulan kontrak antara pihak-pihak yang berinteraksi di dalam perusahaan (stakeholders). Masing-masing pihak akan bertindak sesuai dengan kepentingannya sendiri-sendiri sehingga akan muncul kepentingan-kepentingan yang saling berlawanan. Jensen dan Mackling mengawali analisisnya dengan menanyakan apa yang terjadi jika seorang pengusaha (pendiri) memutuskan untuk menjual sebagai kepemilikannya kepada investor luar.

Meek, et al (2003) menyebutkan perusahaan besar mempuyai kemampuan untuk merekrut karyawan yang ahli, serta adanya tuntutan dari pemegang saham dan analis, sehingga perusahaan besar memiliki insentif untuk melakukan pengungkapan yang lebih lengkap dari pada perusahaan kecil. (Fitriany, 2001)

\section{Likuiditas}

Likuiditas merupakan rasio yang menunjukan menunjukan kemampuan perusahaan dalam memenuhi kewajiban jangka pendeknya. Semakin tinggi rasio likuiditas, maka semakin baik kemampuan perusahaan dalam memenuhi kewajiban jangka pendeknya. Rasio yang digunakan adalah current rasio (CR) yang diukur dengan membagi asset lancar dengan kewajiban lancar. (Priguno, 2013)

\section{Profitabilitas}

Profitabilitas merupakan rasio yang digunakan untuk mengukur efektivitas manajemen secara keseluruhan yang ditujukan besar kecilnya tingkat keuntungan yng diperoleh dalam penjualan maupun investasi. (Fahmi, 2014)

Semakin tinggi rasio profitabilitas menunjukan semakin tinggi kemampuan perusahaan dalam memperoleh laba dan semakin baik kinerja perusahaannya. Oleh karena itu 
perusahaan dengan profitabilitas tinggi akan lebih berani mengungkapkan laporan keuangan dan semakin tinggi tingkat pengungkapan laporan keuangan.

\section{Manajemen Laba}

Manajemen laba merupakan cara yang ditempuh oleh manajemen dalam mengelola perusahaan melalui kebikan akuntyansi tertentu dengan meningkatkan atau menurukan laba bersih untuk kepentingan pribadi. (Badzurahman, 2013)

\section{METODE PENELITIAN}

Populasi dalam penelitian ini adalah perusahaan yang terdaftar di Bursa Efek Indonesia sektor kimia dan perdagangan eceran yang termasuk dalam katagori High and Low Technology tahun 2014-2018. Teknik pengambilan sampel dengan metode purposive sampling.

Tabel 1

Pemilihan Sampel

\begin{tabular}{|c|l|c|}
\hline No. & \multicolumn{1}{|c|}{ Kriteria } & Jumlah \\
\hline 1. & $\begin{array}{l}\text { Perusahaan sektor Industri Kimia dan termasuk perusahaan High } \\
\text { Technology }\end{array}$ & 11 \\
\hline 2. & $\begin{array}{l}\text { Perusahaan sektor Perdagangan Eceran dan termasuk } \\
\text { perusahaan Low Technology }\end{array}$ & 25 \\
\hline 3 & $\begin{array}{l}\text { Perusahaan-perusahaan yang sahammnya minimal telah tercatat } \\
\text { di BEI selama 5 periode pengamatan berturut-turut dan tidak } \\
\text { pindah sektor. Hal ini dimaksudkan untuk keperluan perhitungan } \\
\text { dan analisis data. }\end{array}$ & $(7)$ \\
\hline 4 & $\begin{array}{l}\text { Perusahaan yang 5 tahun berturut-turut melakukan delisting. } \\
\text { keuangannya tidak mneggunakan mata uang Rupiah }\end{array}$ & $(5)$ \\
\hline 5. & $\begin{array}{l}\text { Perusahaan yang akan diteliti mengungkapkan laporan } \\
\text { Perusahaan mempublikasikan laporan keuangan periode 2014- } \\
\text { audit. }\end{array}$ & - \\
\hline \multicolumn{2}{|c|}{ 6. } \\
\hline Jumlah sampel
\end{tabular}

Sumber: Data diolah sendiri (2019)

\section{DEFINISI OPERASIONA DAN PENGUKURAN VARIABEL}

Variabel merupakan apa pun yang bisa membedakan atau membawa variasi pada nilai. Nilai bisa berbeda pada waktu dan objek atau orang yang sama, atau pada waktu yang sama untuk objek orang yang berbeda. (Sekaran, 2006)

\section{Likuiditas (X1)}

Likuiditas merupakan rasio yang menunjukan kemampuan perusahaan untuk membayar kewaajiban jangka pendek tepat pada waktunya (Sartono, 2010). Likuiditas dalam penelitian ini diproksikan dengan Rasio Lancar (current ratio): 


$$
\text { Rasio Lancar }=\frac{\text { AssetLancar }}{\text { Kewajiban Lancar }}
$$

\section{Profitabilitas (X2)}

Profitabilitas digunakan untuk mengukur sampai seberapa besar efektivitas manajemen dalam mengelola asset dan ekuitas yang dimiliki perusahaan untuk menghasilkan laba (Halim, 2002). (Johar, 2007) rasio profitabilitas digunakan untuk mengukur seberapa besar kemampuan perusahaan memperoleh laba dalam hubungan dengan penjualan, asset, maupun laba atau modal sendiri.

Variabel ini menggunakan rumus:

$$
\mathrm{ROA}=\frac{E A T}{\text { Total } \text { Asset }}
$$

\section{Manajemen Laba (X3)}

Jones (1991) mengembangkan model earnings management dengan membagi total akrual perusahaan menjadi non-discretionary accrual (tingkat akrual yang wajar) dan discretionary accruals (tingkat akrual yang abnormal). Indikasi adanya earnings management dapat dilihat dari laporan keuangan yang disajikan oleh perusahaan.

Proksi Manajemen Laba menggunakan non-discretionary accruals menggunakan model Jones (1991): (Sulistyanto, 2018)

$$
\mathrm{NDA}_{\mathrm{t}}=\alpha 1 \frac{1}{A_{\mathrm{t}-1}}+\alpha 2 \frac{D R E V}{T A_{\mathrm{t}-1}}+\alpha 3 \frac{P P E}{T A}
$$

Keterangan Notasi:

$\triangle \mathrm{REV}_{\mathrm{t}}$

: Pendapatan tahun t dikurangi pendapatan $\mathrm{t}-1$.

$\mathrm{PPE}_{\mathrm{t}}$

: Gross property, plant, and equipment periode t.

TA $t-1$

: Total aktiva periode $\mathrm{t}-1$.

$\alpha 1, \alpha 2, \alpha 3$

: Firm spesific parameters.

Estimasi $\alpha 1, \alpha 2, \alpha 3$ dihitung selama periode estimasi dengan menggunakan model sebagai berikut:

$$
\frac{T A C_{t}}{T A_{t-1}}=\alpha 1\left[\frac{1}{T A_{t-1}}\right]+\alpha 2\left[\frac{\Delta R E V_{t}}{T A_{t-1}}\right]+\alpha 3\left[\frac{P P E_{t}}{T A_{t-1}}+v t\right]+\sum
$$

Keterangan Notasi:

$\mathrm{TAC}_{\mathrm{t}}$ : Total Akrual

\section{PENGUNGKAPAN SUKARELA (Y)}

Variabel Dependen yang digunakan dalam penelitian ini adalah pengungkapan sukarela. Tingkat kelengkapan voluntary disclosure dinyatakan dalam Indeks Kelengkapan 
Pengungkapan Sukarela (IKP Sukarela). Menghitung indeks kelengkapan pengungkapan setiap perusahaan dengan rumus:

$$
\mathrm{IKP}=\frac{N}{K}
$$

Dimana:

$\mathrm{N} \quad$ : Skor total yang diperoleh

K : Skor total yang diharapkan

IKP: Indeks Kelengkapan Pengungkapan

Sumber: (Fitriany, 2001)

\section{HASIL DAN PEMBAHASAN}

Berdasarkan hasil data memperoleh deskripsi data padea table berikut:

\section{Statistik deskriptif}

Tabel 2

Hasil Uji Statistik Deskriptif Descriptive Statistics

\begin{tabular}{|l|r|r|r|r|r|}
\hline & $\mathrm{N}$ & $\begin{array}{r}\text { Minimu } \\
\mathrm{m}\end{array}$ & $\begin{array}{r}\text { Maximu } \\
\mathrm{m}\end{array}$ & Mean & \multicolumn{2}{l|}{$\begin{array}{l}\text { Std. } \\
\text { Deviation }\end{array}$} \\
\hline LIKUIDITAS & 95 & .15 & 2.78 & 1.0577 & .68038 \\
PROFITABILITAS & 95 & .07 & .47 & .2376 & .10457 \\
MANAJEMEN_LAB & 95 & .25 & .92 & .5121 & .16158 \\
A & & & & & \\
PENGUNGKAPAN & & & & & \\
SUKARELA & 95 & .75 & .90 & .8374 & .03094 \\
Valid N (listwise) & 95 & & & & \\
\hline
\end{tabular}

Sumber : Output SPSS 22, data sekunder diolah 2019.

Dari hasil uji statistik deskriptif didapatkan informasi sebagai berikut:

1. Data dari Likuiditas menunjukkan nilai maksimum (tertinggi) dari Likuiditas perusahaan kimia dan perdagangan eceran yang menjadi sampel dalam penelitian ini adalah sebesar 2,78. Nilai minimumnya sebesar 0,15 , nilai mean (rata-rata) sebesar 1,0577. Sedangkan standar deviasinya sebesar 0,68038, maka nilai rata-rata lebih besar dari standar deviasinya, sehingga mengindikasi kualitas data dari variabel ini baik dan penyebaran data menunjukkan hasil yang normal.

2. Data dari Profitabilitas menunjukkan nilai maksimum (tertinggi) dari Profitabilitas perusahaan kimia dan perdagangan eceran yang menjadi sampel dalam penelitian ini adalah sebesar 0,47. Nilai minimum dari profitabilitas adalah sebesar 0,07. Nilai mean (rata-rata) sebesar 0,2376 sedangkan standar deviasinya sebesar 0,10457, maka nilai 
rata-rata lebih besar dari standar deviasinya, sehingga mengindikasi kualitas data dari variabel ini baik dan penyebaran data menunjukkan hasil yang normal.

3. Data dari Manajemen Laba menunjukkan nilai maksimum (tertinggi) dari perusahaan perusahaan kimia dan perdagangan eceran yang menjadi sampel dalam penelitian ini adalah sebesar 0,92. Nilai minimum dari ukuran perusahaan adalah sebesar 0,25. Nilai mean (rata-rata) sebesar 0,5121, sedangkan standar deviasinya sebesar 0,16158, maka nilai rata-rata lebih besar dari standar deviasinya, sehingga mengindikasi kualitas data dari variabel ini baik dan penyebaran data menunjukkan hasil yang normal.

4. Data dari Pengungkapan Sukarela (Voluntary Disclosure) menunjukkan nilai maksimum (tertinggi) dari ukuran perusahaan perusahaan kimia dan perdagangan eceran yang menjadi sampel dalam penelitian ini adalah sebesar 0,90. Nilai minimum dari Pengungkapan Sukarela (Voluntary Disclosure) adalah sebesar 0,75. Nilai mean (rata-rata) sebesar 0,8374, sedangkan standar deviasinya sebesar 0,03094, maka nilai rata-rata lebih besar dari standar deviasinya, sehingga mengindikasi kualitas data dari variabel ini baik dan penyebaran data menunjukan hasil yang normal.

\section{Uji Normalitas}

Tabel 3

Hasil Uji Kolmogorov-Sminov

One-Sample Kolmogorov-Smirnov Test

\begin{tabular}{|ll|r|}
\hline & & $\begin{array}{c}\text { standardized } \\
\text { Residual }\end{array}$ \\
\hline Normal Parameters ${ }^{\mathrm{a}, \mathrm{b}}$ & Mean & 95 \\
& Deviation & .0000000 \\
Most Extreme & Absolute & .02928200 \\
Differences & Positive & .052 \\
& Vegative & .027 \\
Statistic & & .052 \\
Asymp. Sig. (2-tailed) & & $.200^{\mathrm{c}, \mathrm{c}}$ \\
\hline
\end{tabular}

Sumber: Output SPSS 22, data sekunder diolah 2019

Berdasarkan hasil uji kolomogrov-smirnov dengan asymp sig. sebesar 0,200 >0,05, yang berarti data dalam penelitian ini terdistribusi secara normal. Model regresi dalam penelitian ini terdistribusi normal karena tingkat signifikansi $>0,05$. 
Uji Multikolonieritas

Tabel 4

Hasil Uji Multikolonieritas

\begin{tabular}{|c|c|c|c|c|c|c|c|}
\hline \multicolumn{8}{|c|}{ Coefficients ${ }^{2}$} \\
\hline \multirow[b]{2}{*}{ Model } & \multicolumn{2}{|c|}{$\begin{array}{l}\text { Unstandardized } \\
\text { Coefficients }\end{array}$} & \multirow{2}{*}{\begin{tabular}{|l|}
$\begin{array}{l}\text { Standardimed } \\
\text { Coefficients }\end{array}$ \\
Beta \\
\end{tabular}} & \multirow[b]{2}{*}{$\mathrm{T}$} & \multirow[b]{2}{*}{ Sig. } & \multicolumn{2}{|c|}{$\begin{array}{l}\text { Collinearity } \\
\text { Statistics }\end{array}$} \\
\hline & $\mathrm{B}$ & $\begin{array}{l}\text { Std. } \\
\text { Etror }\end{array}$ & & & & Tolerame & VIF \\
\hline (Constant) & .832 & .012 & & 67.666 & .000 & & \\
\hline LIKUIDITAS & -.013 & .005 & -.291 & -2.829 & .006 & .933 & 1.072 \\
\hline PROFITABILITAS & .061 & .031 & .207 & 2.002 & .048 & .917 & 1.090 \\
\hline MANEJEMEN_LABA & .010 & .019 & .051 & .505 & .615 & .976 & 1.024 \\
\hline
\end{tabular}

Sumber: Output SPSS 22, data sekunder diolah 2019

Dari hasil perhitungan uji multikolineritas diperoleh nilai VIF masing-masing yaitu 1,072; 1,090 dan 1,024. Nilai VIF dari tiga variabel bebas tersebut lebih kecil dari batas nilai VIF yang diperkenankan yaitu maksimal sebesar 10. Dapat disimpulkan bahwa model regresi dalam penelitian ini tidak terdapat multikolineritas.

\section{Uji Heteroskedastisitas}

\section{Tabel 5}

\section{Hasil Uji Heteroskedastisitas}

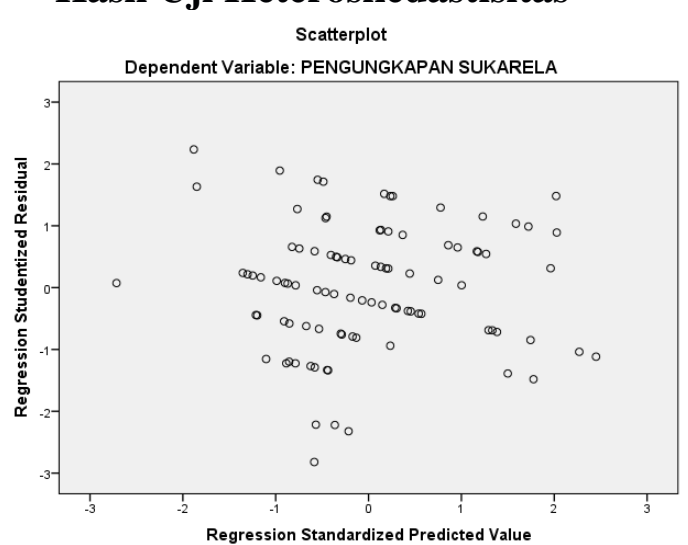

Berdasarkan grafik Scatterplot menunjukkan bahwa tidak ditemukan pola tertentu yang teratur, dan titik-titik menyebar diatas dan di bawah angka 0 pada sumbu Y. Artinya tidak terjadi heteroskedastisitas pada model regresi.

\section{Tabel 6}

\section{Hasil Uji Autokorelasi}

Model Summaryb

\begin{tabular}{|c|c|c|c|c|c|c|c|c|c|c|}
\hline \multirow[b]{2}{*}{ Model } & \multirow[b]{2}{*}{ square } & \multirow[b]{2}{*}{$\begin{array}{l}\mathrm{A} \\
\mathrm{R}\end{array}$} & \multirow[b]{2}{*}{$\begin{array}{l}\text { Adjusted } \\
\text { Square }\end{array}$} & \multirow{2}{*}{$\begin{array}{c}\text { Error of } \\
\text { the } \\
\text { Estimate }\end{array}$} & \multicolumn{5}{|c|}{ Change Statistics } & \multirow[b]{2}{*}{$\begin{array}{l}\text { Durbin- } \\
\text { Watson }\end{array}$} \\
\hline & & & & & \begin{tabular}{|l|} 
Square \\
Change
\end{tabular} & \begin{tabular}{|c|}
$\mathrm{F}$ \\
Change
\end{tabular} & df1 & df2 & $\begin{array}{c}\text { Sig. F } \\
\text { Change }\end{array}$ & \\
\hline & .104 & & .075 & .02976 & .104 & 3.523 & 3 & 91 & .018 & 2.016 \\
\hline
\end{tabular}

Sumber: Output SPSS 22, data sekunder diolah 2019 
Berdasarkan hasil uji SPSS 22, menunjukkan hasil sebesar 2.016 dengan jumlah variabel bebas sebanyak 3 variabel dan tingkat signifikansi 0,05 atau $\alpha=5 \%$. Dari uji tersebut menunjukkan hasil DU < Durbin Watson< DL, yaitu 1,7316<2,016<1,6015 artinya tidak terdapat autokorelasi dalam penelitian yang dilakukan.

\section{Analisis Regresi Linier Berganda}

\section{Tabel 7}

Hasil Regresi Analisis Linier Berganda.

Coefficients $^{*}$

\begin{tabular}{|c|c|c|c|c|c|}
\hline \multirow[b]{2}{*}{ Model } & \multicolumn{2}{|c|}{$\begin{array}{l}\text { Unstandardiaed } \\
\text { Coefficients }\end{array}$} & \multirow{2}{*}{\begin{tabular}{|l}
$\begin{array}{l}\text { Standardized } \\
\text { Coefficients }\end{array}$ \\
Beta \\
\end{tabular}} & \multirow[b]{2}{*}{$\mathrm{T}$} & \multirow[b]{2}{*}{ Siz. } \\
\hline & B & Std. Eror & & & \\
\hline (Constant) & .832 & .012 & & 67.666 & .000 \\
\hline 1 LIKUIDITAS & -.013 & .005 & -.291 & -2.829 & .006 \\
\hline $\begin{array}{l}\text { PROFITABITA } \\
S\end{array}$ & .061 & .031 & .207 & 2.002 & .048 \\
\hline $\begin{array}{l}\text { [EHEJEMEH_LA } \\
\text { BA }\end{array}$ & .010 & .019 & .051 & .505 & .615 \\
\hline
\end{tabular}

Sumber: Output SPSS 22, data sekunder diolah 2019

Berdasarkan persamaan regresi linier berganda didapat persamaan:

$\mathrm{Y}=\alpha-\beta 1 \mathrm{X} 1+\beta 2 \mathrm{X} 2+\beta 3 \mathrm{X} 3+\mathrm{e}$

$\mathrm{Y}=0,832-0,013 \mathrm{X} 1+0,061 \mathrm{X} 2+0,010 \mathrm{X} 3+\mathrm{e}$

1) Dari hasil persamaan di atas diperoleh nilai konstanta $(\alpha)$ sebesar 0,832 artinya jika likuiditas, profitabilitas dan manajemen laba dianggap tetap atau 0 , maka pengungkapan sukarela sebesar 0,832 .

2) Variabel likuiditas diperoleh nilai $\beta$ sebesar $-0,013$ berarti setiap kenaikan 1 dari rasio likuiditas maka tingkat pengungkapan sukarela juga akan turun 1,3 satuan.

3) Variabel profitabilitas diperoleh nilai $\beta$ sebesar 0,061 dengan tanda positif, berarti setiap kenaikan 1 dari profitabilitas, maka tingkat pengungkapan sukarela akan naik sebesar 6,1 satuan dianggap tetap dan konstan.

4) Variabel manajemen laba diperoleh nilai $\beta$ sebesar 0,010 , dengan tanda positif yang berarti setiap kenaikan 1 dari manajemen laba, maka tingkat pengungkapan sukarela naik sebesar 1,0 satuan.

Tabel 8

Hasil Uji Kelayakan (Uji F)

ANOVA $^{a}$

\begin{tabular}{|r|r|l|l|l|l|}
\hline Model & \multicolumn{1}{|c|}{$\begin{array}{c}\text { Sum of } \\
\text { Squares }\end{array}$} & Df & \multicolumn{1}{|c|}{$\begin{array}{c}\text { Mean } \\
\text { Square }\end{array}$} & F & \multicolumn{1}{l|}{ Sig. } \\
\hline Regression & .009 & 3 & .003 & 3.523 & $.018^{\mathrm{b}}$ \\
\hline
\end{tabular}




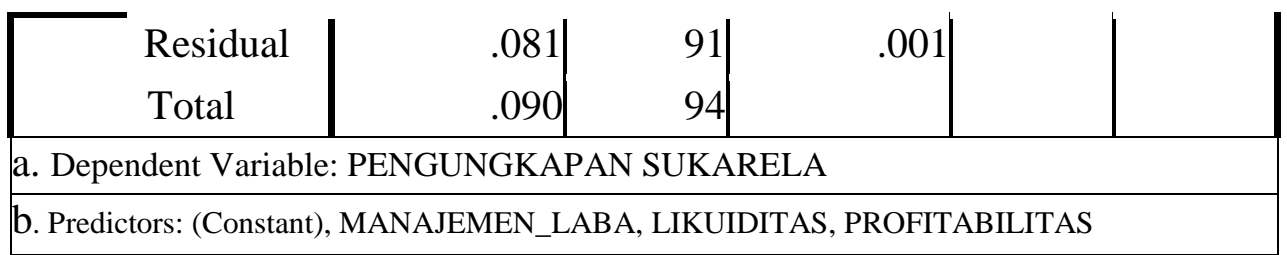

Sumber: Output SDPSS 22, data sekunder diolah 2019

Berdasarkan tabel dapat dilihat bahwa nilai $\mathrm{F}$ hitung sebesar 3,523 dengan tingkat signifikansi 0,018 dalam penelitian ini menggunakan taraf signifikansi 5\% atau 0,05 maka dapat disimpulkan bahwa Likuiditas, Profitabilitas dan Manajemen Laba berpengaruh secara simultan terhadap Pengungkapan Sukarela.

\section{Tabel 9}

Uji Kelayakan (Uji F)

Coefficients $^{\mathrm{a}}$

\begin{tabular}{|c|c|c|c|c|c|}
\hline \multirow[b]{2}{*}{ Model } & \multicolumn{2}{|c|}{$\begin{array}{c}\text { Unstandardized } \\
\text { Coefficients }\end{array}$} & \multirow{2}{*}{\begin{tabular}{|c|}
$\begin{array}{c}\text { Standardized } \\
\text { Coefficients }\end{array}$ \\
Beta \\
\end{tabular}} & \multirow[b]{2}{*}{$\mathrm{T}$} & \multirow[b]{2}{*}{ Sig. } \\
\hline & $\mathrm{B}$ & ttd. Error & & & \\
\hline Constant) & .832 & .012 & & 67.666 & .000 \\
\hline LIKUIDITAS & -.013 & .005 & -.291 & -2.829 & .006 \\
\hline $\begin{array}{l}\text { PROFITABILIT } \\
\text { AS }\end{array}$ & .061 & .031 & .207 & 2.002 & .048 \\
\hline $\begin{array}{l}\text { MANAJEMEN_L } \\
\text { ABA }\end{array}$ & .010 & .019 & .051 & .505 & .615 \\
\hline
\end{tabular}

Sumber: Output SPSS 22, data sekunder diolah 2019.

Tabel diatas menunjukan hasil uji statistik $\mathrm{t}$ antaran variabel indpenden dengan variabel dependen. Variabel Likuiditas memiliki t hitung sebesar -2,829 satuan dengan tingkat signifikan 0,006. Tingkat signifikansi tersebut lebih kecil dari 0,05 yang berarti H1 diterima. Sehingga dapat dikatakan bahwa variabel Likuiditas berpengaruh terhadap Pengungkapan Sukarela.

Variabel Profitabilitas memiliki t hitung sebesar 2,002 satuan dengan tingkat signifikan 0,048. Tingkat signifikansi tersebut lebih kecil dari 0,05 yang berarti $\mathrm{H} 2$ diterima. Sehingga dapat dikatakan bahwa variabel Profitabilitas berpengaruh terhadap Pengungkapan Sukarela.

Variabel Manajemen Laba memiliki t hitung sebesar 0,505 satuan dengan tingkat signifikan 0,615. Tingkat signifikansi tersebut lebih besar dari 0,05 yang berarti H3 ditolak. Sehingga dapat dikatakan bahwa variabel Manajemen Laba tidak berpengaruh terhadap Pengungkapan Sukarela.

Tabel 10

Hasil Analisis Koefisien Determinasi

\begin{tabular}{|c|c|c|c|c|c|c|}
\hline \multirow[b]{2}{*}{ Model } & \multirow[b]{2}{*}{$\mathrm{R}$} & \multirow[b]{2}{*}{ Square } & \multirow[b]{2}{*}{$\begin{array}{c}\text { Adjusted R } \\
\text { Square }\end{array}$} & \multirow[b]{2}{*}{$\begin{array}{c}\text { Error of the } \\
\text { Estimate }\end{array}$} & \multicolumn{2}{|c|}{ Change Statistics } \\
\hline & & & & & $\begin{array}{r}\text { R Square } \\
\text { Change }\end{array}$ & Change \\
\hline & $.323^{\mathrm{a}}$ & .104 & .075 & .02976 & .104 & 3.523 \\
\hline
\end{tabular}

Sumber: Output SPSS 22, data sekunder diolah 2019 
Berdasarkan Tabel 4.6, nilai koefisien determinasi $\mathrm{R}^{2}$ terletak pada kolom Adjusted $R$ Square. Diketahui nilai koefisien determinasi sebesar $\mathrm{R}^{2}=0,075$. Nilai tersebut berarti seluruh variabel bebas, yaitu Likuiditas, Profitabilitas, Manajemen Laba secara simultan mempengaruhi variabel pengungkapan sukarela.

\section{KESIMPULAN}

Berdasarkan hasil penelitian dan pembahasan di bab sebelumnya, maka diperoleh kesimpulan bahwa:

1) Likuiditas memiliki tingkat signifikansi dibawah 0,05 yaitu sebesar 0,006 . Hal tersebut menunjukan bahwa likuiditas signifikan terhadap Pengungkapan Sukarela (Voluntary Disclosure), H1 diterima.

2) Profitabilitas memiliki tingkat signifikansi dibawah 0,05 yaitu serbesar 0,048. Hal tersebut menunjukan bahwa profitabilitas signifikan terhadap Pengungkapan Sukarela (Voluntary Disclosure), $\mathrm{H} 2$ diterima.

3) Manajemen Laba memiliki tingkat signifikansi diatas 0,05 yaitu sebesar 0,615. Hal tersebut menunjukan bahwa manajemen laba tidak signifikan terhadap Pengungkapan Sukarela (Voluntary Disclosure), H3 ditolak.

4) Diketahui nilai koefisien determinasi sebesar $R^{2}=0,075$. Nilai tersebut berarti seluruh variabel bebas, yaitu Likuiditas, Profitabilitas, Manajemen Laba secara simultan mempengaruhi variabel pengungkapan sukarela.

\section{SARAN}

Beberapa saran yang dapat penulis berikan sehubungan dengan hasil penelitian ini adalah:

1. Bagi perusahaan, sebaiknya melakukan pengungkapan sukarela dalam laporan tahunan yang lebih detail dan luas agar dapat memberikan informasi yang tepat dalam pengambilan keputusan oleh pihak internal maupun pihak eksternal.

2. Bagi peneliti selanjutnya terkait pengungkapan sukarela perlu menggunakan itemitem terkini yang berlaku dengan peraturan OJK untuk perusahaan go public di Indonesia.

3. Peneliti selanjutnya dapat mengembangkan variabel lain yang berpengaruh terhadap pengungkapan sukarela seperti umur perusahaan, kepemilikan manajerial .

\section{DAFTAR PUSTAKA}

Ainun, F. R. (2000). Analisis Hubungan Antara Kelengkapan Laporan Keuangan degan Struktur Modal dan Tip Kepemilikan Perusahaan. Jurnal Ekonomi dan Bisnis Indonesia. Vol. 15 (1) , 70-82.

Andriyanto, M. M. (2011). Perbandingan Tingkat Kelengkapan Mandatory Disclosure dan Voluntary Disclosure Informasi Akuntansi Antara Industri High-Profile dan LowProfile. Jurnal Akuntansi dan Investasi. Vol. 12, No. 1. Januari , 15-35.

Apsari, R. d. (2011). Faktor yang Mempengaruhi Kelengkapan Penghungkapan Laporan Keuangan Pada Perusahaan Manufaktur yang Terdaftar di BEI . Rofika dan Mustika Debby Apsari Vol. 6, No. 2, Oktober , 99-109. 
Arifin, Z. (2015). Teori Keuangan dan Pasar Modal . Yogyakarta: Badan Penerbit Ekonisia Fakultas Ekonomi UII.

Ariyanti, T. (2015). Pengaruh Ukuran Perusahaan, Likuiditas, Leverage dan Profitabilitas Pada Kelengkapan Laporan Keuangan. Naskah Publikasi , 1-12.

Ariyanti, T. (2015). Pengaruh Ukuran Perusahaan, Likuiditas, Leverage dan Profitabilitas pada Kelengkapan Penbgungkapan Laporan Keuangan . Universitas Muhammadiyah Surakarta , 1-12.

bachtiar, s. v. (2003). hubungan antara manajemen laba dengan tingkat pengungkapan laporan keuangan. hubungan anatara manajemen laba dengan tingkat pengungkapan laporan keuangan, 328-381.

Bachtiar, S. V. (2003). Hubungan Antara Manajaemen Laba dengan Tingkat Pengungkapan Laporan Keuangan. Simposium Nasional Akuntansi VI (SNA) , 328-381.

Baridwan, Z. (2004). Intermediate Accouting Edisi Kedelapan. Yogyakarta: BPFE Yogyakarta.

Baskaningrum, N. K. (2013). Pengngkapan Sukarela Laporan Keuangan Tahunan dan FaktorFaktor Yang Mmempengaruhi (Studi pada Saham-Saham LQ-45 di Bursa Eek Indonesia periode 2010-2011). E-Jurnal Akuntansi - ojs.unud.ac.id. Vol. 2, No. 1. Januari .

Belkaoui, A. R. (2000). Teori Akuntansi. Jakarta: Salemba Empat.

Belkoui, A. R. (2003). Accounting: by principle or design . Westport (Conn.) by Preager.

Budiasih, N. M. (2016). Profitabilitas Dan Corporate Social Responsibility Pada Perusahaan High And Low Profile e e-Journal Akuntansi Univesitas Udayana Vol. 14, No.2. Februari, 977-1004.

Cooke, T. (1992). The Impact of Size, Stock Market Listing and Industry Type on Disclosure in The Annual Reports of Japanese Listed Corporations. Accounting and Business Research, 229-237.

Daniel, N. U. (2013). Pengaruh Ukuran Perusahaan, Leverage, dan Likuiditas terhadap Luas Pengungkapan Laporan Keuangan . Padang: Universitas Negeri Padang .

Deegan, C. (2004). Financial Accounting Theory . Australia: McGraw Hill.

Dibiyantoro. (2011). Pengaruh Struktur Modal dan Profitabilitas Terhadap Mandatory Disclosure Financial Statment Pada Perusahaan Mnufaktur Yang Terdaftar di BEI. Jurnal Eonomi dan Informasi Akuntansi (JENIUS). Mei. Vol. 1, No.2 .

Dillak, H. L. (2018). Pengungkapan Laporan Keuangan: Ukuran Perusahaan, Likuiditas, Leverage dan Profitabilitas. e-Proceeding of Management. Vol. 5, No. 1. Maret, 852-859.

Fahmi, I. (2014). Pengantar Manajemen Keuangan. Bandung: Alfabeta.

Farihah, D. S. (2016). Pengaruh Ukuran Perusahaanj dan Kepemilikan Manajerial Terhadap Pengungkapan Laporfan Keuangan (Studi pada Perusahaan Real Estate yang terdaftar di BEI) . Jurnal Akuntansi. Vol. 3, No. 2. Juli , 101-111.

Fitriana, N. L. (2014). Faktor-Faktor yang Mmepengaruhi Luas Pengungkapan Sukarela dalam Annual Report. . Diponegoro Jounal of Accounting . Vol. 3 , 1-10. 
Fitriany. (2001). Signifikansi Perbedaan Tingkat Kelengkapan Pengungkapan Wajib dan Sukarela Pada Laporan Keuangan Perusahaan Publik yang Terdaftar di Bursa Efek Jakarta. Simposium Akuntansi IV .

Ghozali, A. C. (2007). Teori Akuntansi . Semarang : Badan Penerbit Universitas Diponegoro.

Ghozali, I. (2018). Aplikasi Analisis Multivariate Dengan Program IBM SPSS 25 . Semarang: Badan Penerbit Universitas Diponegoro.

Gita Mustika, R. N. (2015). Penagruh Manajemen Laba Terhadap Pengungkapan Corporate Social Responsibility: Variabel Anteseden dan Variabel Moderasi. Akuntabilitas Vo. VIII, No. 3. Desember , 238-253.

Halim, A. (2002). Analisis Investasi . Jakarta: Salemba Empat.

Henny Larasati, L. S. (2018). Pengungkapan Laporan Keuangan: Ukuran Perusahaan, Likuiditas, Leverage dan Profitabilitas. e-Procedding Management: Vol. 5, No. 1, Maret , 853-858.

Hery. (2016). Mengenal Dan Memahami Dasar-Dasar Laporan Keuangan. Jakarta: PT. Grasindo.

Jerry J. Weygandt, D. E. (2015). Accounting Principles: Edisi 7 Buku 2. Jakarta : Salemba Empat .

Johar, A. (2007). Cara Cerdas Menilai Kinerja Perusahaan . Jakarta: PT. Elex Media Komputindo.

Kharisma Dwi Citra Sari, M. A. (2016). Pengaruh Profitabilitas, Leverage, Likuiditas, dan Ukuran Perusahaan Terhadap Ketepatan Pengungkapan Laporan Keuangan pada Perusahaan Subsektor Property dan Real Estate yang terdaftar di Bursa Efek Indonesia periode 2011-2014. Jurnal e-Proceeding Management: Vol. 3, No. 1. April , 116-123.

Lan, Y. e. (2013). Determinants and Features of Voluntary Disclosure in the Chinese Stock Market. China Journal of Accounting Research 6. , 265-285.

Masyitah, E. (2016). Faktor-Faktor yang Mempengaruhi Pengungkapan Ssosial (Social Disclosure) dalam Laporan Keuangan Tahunan Perusahaan Manufaktur yang terdaftar di Bursa Efek Indonesia . Jurnal Al-Qasd, Vol. 1, No. 1, Agustus , 52-70.

Metalia, R. W. (2011). Perbandingan Tingkat Kelengkapan Mandatory Disclosure dan Voluntary Disclosure Informasi Akuntansi Antara Industri High-Profile dan LowProfile . Jurnal Akuntansi dan Investasi. Vol.12, No. 1. Januari , 15-35.

Neliana, T. (2018). PENGUNGKAPAN SUKARELA LAPORAN TAHUNAN DAN FAKTOR-FAKTOR YANG MNEMPENGARUHI . Jurnal Akuntansi dan Keuangan Vol. 7 No. 1, April , 79-97.

Priyadi, D. L. (2016). Pengaruh Karateristik Perusahaan pada Luas Pengungkapan Sukarela dan Implikasinya terhadap Asimetri Informasi.Jurnal Ilmu dan Riset Akuntansi Vol. 5 No. 2

Saputra, E. (2015). Faktor- Faktor Yang Mempengaruhi Luas Pengungkapang Sukarela dan Implikasinya Terhadap Aimetri Informasi. (Studi Pada Perusahaan Manufaktur Yang Terdaftar di Bursa Efek Indonesia Periode 2012-2014. Universitas Maritim Raja Ali Haji .

Sartono, A. (2010). Manajemen Keuangan Edisi keempat. Yogyakarta: BPFE. 
Sastradipraja. (2010). Analisis dan PenggunaAn Laporan Keuangan (Program Studi S1). Bandung: Universitas Widyatama .

Scoot, W. R. (1997). Financial Accounting Theory. USA: Prentice-Hall.

Sekaran, U. (2006). Research Methods For Business: Edisi Keempat Buku 1. Jakarta: Salemba Empat.

Sekaran, U. (2006). Research Methods For Business: Edisi Pertama . Jakarta: Salemba Empat.

Suharto, A. B. (2016). Beberapa Faktor yang Mempengaruhi Disclosure Laporan Keuangan: Stusi Empiris pada Perusahaan Property dan Real Estate. Bandung: LPPM Universitas Islam Nusantara.

Sulistyanto, H. S. (2018). Manajemen Laba: Teori dan Model Empiris. Jakarta: PT. Grasindo, Anggota Ikapi.

Suwardjono. (2005). Teori Akuntansi. Yogyakarta: BPFE UGM.

Syafri, S. (2006). Ananlisa Kritis Atas Laporan Keuangan. Jakarta: PT. Raja Grafindo Persada.

Tobing, R. T. (2005). Pengaruh Manajemen Laba Pada Tingkat Pengungkapan Laporan Keuangan Pada Perusahaan Manufaktur Yang Termasuk dalam Indek LQ-45. SNA VIII, Solo, September, 117-135.

Wardani, R. P. (2012). Faktor-Faktor Yang Mmempengaruhi Luas Pengungkapan Sukarela . Jurnal Akuntansi dan Keuangan Vol. 14 No. 1, Mei , 1-5.

Widianingsih, Y. P. (2011). Pengaruh Likuiditas dan Profitabilitas Terhadap Pengungkapan Sukarela Laporan Tahunan. . Politeknosains. Vol. X No. 2 .

Wiguna, P. W. (2013). Pengaruh Leverage, Ukuran Perusahan, Profitabilitas Terhadap Luas Pengunkapan. E-Jurnal Akuntansi Universitas Udayana. Vol. 2 .

Wikartika, E. P. (2014). Analisis Voluntary Disclosure Perusahaan Telekomunikasi di BEI . Jurnal Neo-Bis Vol. 8, No.2, Desember, 101-115.

Wild, K. S. (2014). Analisis Laporan Keuangan: Edisi 10 Buku 1. Jakarta : Salemba Empat. Wild, K. S. (2010). Analisis Laporan Keuangan: Edisi 10 Buku 2 . Jakarta : Salemba Empat. Zaenal, A. (2015). Teori Keuangan dan Pasar Modal . Yogyakarta: Badan Penerbit Ekonisa Fakultas Ekonomi UII. 